\title{
Broad Ligament Ectopic Pregnancy
}

\author{
Charleen Sze-yan Cheung, MBBS, Vincent Y.T. Cheung, MBBS \\ Department of Obstetrics and Gynaecology, Queen Mary Hospital, The University of Hong Kong, Hong Kong, China \\ (both authors).
}

\begin{abstract}
Broad ligament ectopic pregnancy is a rare form of ectopic pregnancy. A 30-year-old nulliparous woman with a history of right salpingectomy for tubal pregnancy presented with vaginal spotting at 6 weeks' amenorrhea. Pelvic sonography revealed a possible viable right tubal stump pregnancy. On laparoscopy, a 3-cm broad ligament ectopic pregnancy was found. Laparoscopic removal of the gestational tissues followed by suturing placed at the bleeding implantation site was performed. Seventeen recent cases of broad ligament ectopic pregnancy were reviewed. With advances in sonography and laparoscopic skills, more cases can be diagnosed in the first trimester and can be safely managed laparoscopically.
\end{abstract}

Key Words: Broad ligament ectopic, Ectopic pregnancy, Intraligamentary pregnancy, Laparoscopy, Sonography

Citation Cheung CS-y, Cheung VYT. Broad ligament ectopic pregnancy. CRSLS e2014.00102. DOI: 10.4293/CRSLS.2014.00102.

Copyright (C) 2014 SLS This is an open-access article distributed under the terms of the Creative Commons Attribution-Noncommercial-ShareAlike 3.0 Unported license, which permits unrestricted noncommercial use, distribution, and reproduction in any medium, provided the original author and source are credited.

Address correspondence to: Vincent Y.T. Cheung, MBBS, Department of Obstetrics and Gynaecology, Queen Mary Hospital, 102 Pokfulam Road, Hong Kong, China Tel: +852-2255-3914, Fax: +852-2855-0947, E-mail: vytc@hku.hk.

\section{INTRODUCTION}

Abdominal pregnancy is a rare but potentially fatal form of ectopic pregnancy. Broad ligament ectopic pregnancy, also known as intraligamentary pregnancy, is considered a kind of abdominal pregnancy with the gestational tissue implanted between the 2 layers of the broad ligament. ${ }^{1-3}$ It has a reported incidence of 1 in 183,900 and occurs in about 1 in 245 ectopic pregnancies. ${ }^{3}$

The clinical presentation of broad ligament ectopic pregnancy is highly variable and can range from asymptomatic early ectopic pregnancy to rupture in labor at term. Accurate preoperative diagnosis is difficult, and very often, definitive diagnosis can be ascertained only at the time of operation.

We report a case of successful laparoscopic management of broad ligament ectopic pregnancy in a woman who had previously undergone salpingectomy for tubal pregnancy. The discussion is followed by a review of reported cases of broad ligament ectopic pregnancy.

\section{CASE DESCRIPTION}

The patient was a 30-year-old nulliparous woman. She had undergone 2 previous surgical terminations of preg- nancy and, 10 years prior to this presentation, a right tubal pregnancy treated by laparoscopic salpingectomy.

The patient had previously had regular cycles and was found to be pregnant 4 weeks after her last menstrual period. She presented to us at 6 weeks' amenorrhea with vaginal spotting and mild abdominal pain. Abdominal and pelvic examination revealed no tenderness. Transvaginal sonography showed a $2.1 \times 1.4 \times 1.9 \mathrm{~cm}$ ringlike lesion with a thick echogenic wall at the right isthmic region, not encircled by myometrium, suggestive of a pregnancy at the stump of the right Fallopian tube. A gestation sac was seen inside the lesion, measuring $1.0 \mathrm{~cm}$ in diameter and containing a small fetal pole measuring $0.2 \mathrm{~cm}$, with fetal heart pulsation seen. No free fluid was noted. The uterus and both ovaries appeared normal. The hemoglobin level was $10.6 \mathrm{~g} / \mathrm{dL}$. The serum human chorionic gonadotropin level was 15,665 IU/L.

During laparoscopy, no hemoperitoneum was found. The right Fallopian tube was absent, consistent with the history of right total salpingectomy. There was a $3-\mathrm{cm}$ bluish swelling noted just lateral to the right uterine cornu, between the 2 leaves of the broad ligament (Figure 1). There was no sign of rupture. The right ovary, left Fallopian tube, and ovary were normal. There was minimal pelvic adhesion.

The broad ligament was opened and the gestational tissue was retrieved. However, there was continued oozing from 


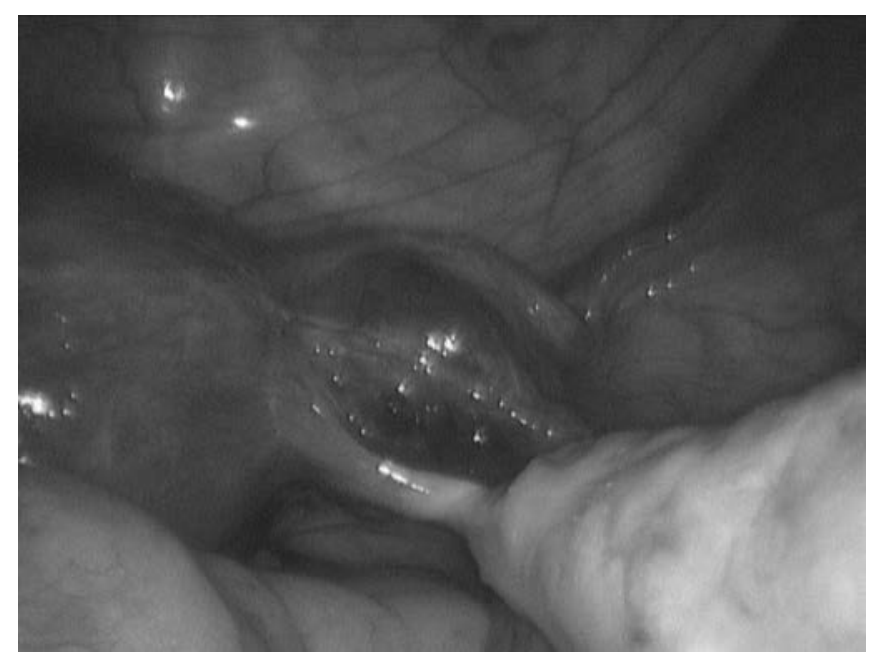

Figure 1. Laparoscopic view of the right broad ligament ectopic pregnancy.

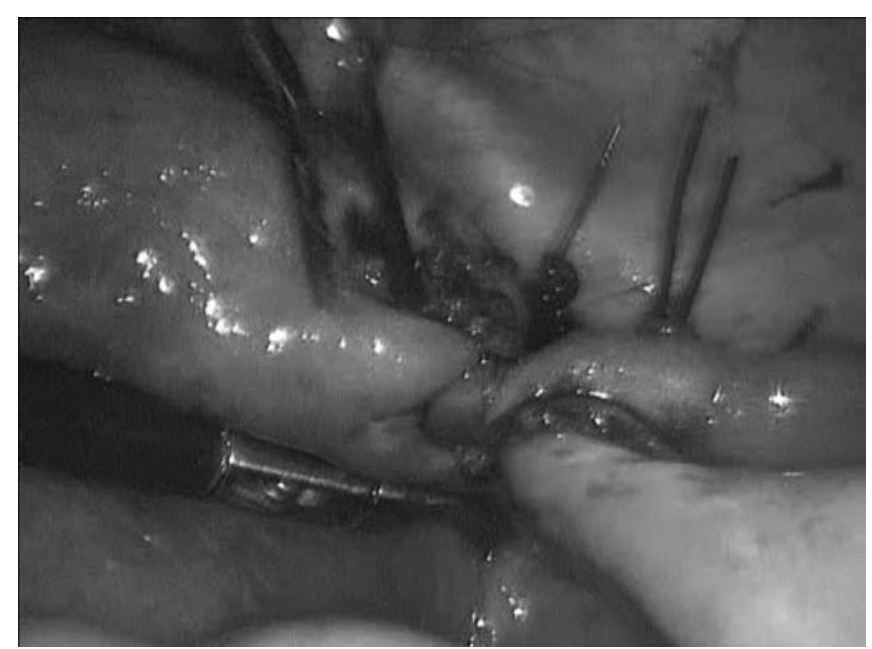

Figure 2. Laparoscopic suturing of the bleeding implantation site.

the implantation site despite the use of bipolar coagulation. Three 1-0 Biosyn stitches were applied to close the implantation site inside the broad ligament to achieve hemostasis (Figure 2). Estimated operative blood loss was $200 \mathrm{~mL}$.

Postoperatively, the patient's hemoglobin level was 9.6 $\mathrm{g} / \mathrm{dL}$. She made an uneventful recovery and was discharged home on the second day. Her human chorionic gonadotropin level dropped to 4,629 IU/L $24 \mathrm{~h}$ after the operation and returned to normal in 4 weeks. Histologic examination of the gestational tissue confirmed products of gestation.

\section{DISCUSSION}

Broad ligament ectopic pregnancy was first described in 1818. Until the 1980s, >100 cases of broad ligament pregnancies were reported, but in almost all cases, the diagnosis was made after 28 weeks' gestation. Given advances in diagnostic and therapeutic technologies, we believed that reviewing more recent cases will provide more relevant clinical insight and perspective on this type of ectopic pregnancy. Therefore, we searched the English literature published since the 1990s and identified 16 cases of broad ligament ectopic pregnancy. ${ }^{1-14}$ Including our own case, a total of 17 cases with their clinical features and outcomes were reviewed (Table 1).

Mechanisms of the development of a broad ligament ectopic pregnancy remain unclear. It can be the result of either primary or secondary implantation at the site. There are several postulations. Unsuspected uterine perforation might occur at the time of embryo transfer. Alternatively, migration of a microscopic fistulous tract in the interstitial portion of the Fallopian tube could lead to subsequent abdominal implantation. The oocyte could be migrated abdominally, where fertilization by spermatozoa from the fistulous tract takes place. Finally, a tubal pregnancy with rupture on the mesosalpingeal border might account for its occurrence.

Broad ligament ectopic pregnancy is more commonly associated with underlying risk factors such as tubal abnormalities, including previous salpingectomy, pelvic infection, endometriosis, or adhesion. In our review, 29.4\% of patients had histories of tubal surgery, mostly ipsilateral salpingectomy. About $12 \%$ were conceived after in vitro fertilization. Given that assisted reproduction is a risk factor for ectopic pregnancy, the increasing trend toward the use of assisted reproductive technologies will likely make this uncommon form of ectopic pregnancy more common. Clinicians should be alerted not only to the possibility of ectopic pregnancy but also to these uncommon forms of ectopic pregnancy.

There were wide variations in the presenting gestational ages and symptoms. The median gestational age at presentation was 10.5 weeks (range, 5-39 weeks). Over the years, more and more patients with broad ligament ectopic pregnancies were diagnosed at earlier gestational ages. Eleven of the 17 patients (64.7\%) in our review presented in the first trimester. The most common presenting symptom reported was abdominal pain (58.8\%), followed by vaginal bleeding (35.3\%). At later gestational age, the diagnosis could often be missed or confounded 
Table 1.

Summary of broad ligament ectopic pregnancies reported in recent literature

\begin{tabular}{|c|c|c|c|c|c|c|c|c|}
\hline Study & $\begin{array}{l}\text { Age, } \\
\text { y }\end{array}$ & Parity & Risk Factors & $\begin{array}{l}\text { Gestational } \\
\text { Age (wk) }\end{array}$ & Presentation & $\begin{array}{l}\text { hCG } \\
(\mathrm{IU} / \mathrm{L})\end{array}$ & $\begin{array}{l}\text { Imaging Findings (USG } \\
\text { if Not Specified) }\end{array}$ & Outcome \\
\hline $\begin{array}{l}\text { Chia et al } \\
(1993)^{3}\end{array}$ & 17 & 0 & Not known & 20 & $\begin{array}{l}\text { Medical termination } \\
\text { of pregnancy }\end{array}$ & NA & $\begin{array}{l}\text { Hysterosalpingography } \\
\text { showed right } \\
\text { extrauterine pregnancy }\end{array}$ & $\begin{array}{l}\text { Laparotomy: right broad } \\
\text { ligament pregnancy }\end{array}$ \\
\hline $\begin{array}{l}\text { Mittal et al } \\
(1994)^{4}\end{array}$ & 28 & 1 & Not known & 30 & $\begin{array}{l}\text { Abdominal pain and } \\
\text { pelvic mass, } \\
\text { maternal } \\
\text { compromise }\end{array}$ & NA & $\begin{array}{l}\text { Suspected placenta } \\
\text { previa with partial } \\
\text { separation }\end{array}$ & $\begin{array}{l}\text { Emergency } \mathrm{C} / \mathrm{S} \text {; delivery } \\
\text { of live birth } 1.43 \mathrm{~kg}\end{array}$ \\
\hline Olsen $(1994)^{6}$ & 29 & $4+2$ & $\begin{array}{l}\text { History of pelvic } \\
\text { inflammatory disease, } \\
\text { left salpingectomy }\end{array}$ & 6 & $\begin{array}{l}\text { Abdominal pain, } \\
\text { vaginal bleeding }\end{array}$ & 59,000 & $\begin{array}{l}\text { Empty uterus, } 3 \times 4 \\
\mathrm{~cm} \text { mass right of } \\
\text { uterus }\end{array}$ & $\begin{array}{l}\text { Laparotomy; excision and } \\
\text { right iliac ligation; second } \\
\text { laparotomy; excision site, } \\
\text { hysterectomy, and right } \\
\text { salpingo-oophrectomy for } \\
\text { hemostasis; histology: } \\
\text { right broad ligament and } \\
\text { left cornual stump } \\
\text { pregnancy }\end{array}$ \\
\hline \multirow[t]{2}{*}{$\begin{array}{l}\text { Cordero et al } \\
(1994)^{1}\end{array}$} & 39 & 0 & Not known & 10 & Abdominal pain & 21,000 & $\begin{array}{l}1.1 \times 1.3 \mathrm{~cm} \text { below } \\
\text { right ovary }\end{array}$ & $\begin{array}{l}\text { Laparotomy; excision of } \\
\text { unruptured right broad } \\
\text { ligament pregnancy }\end{array}$ \\
\hline & 26 & 1 & Obesity & 18 & Abdominal pain & NA & $\begin{array}{l}\text { Extrauterine viable } \\
\text { pregnancy to date }\end{array}$ & $\begin{array}{l}\text { Laparotomy; left broad } \\
\text { ligament pregnancy, no } \\
\text { evidence of prior tubal } \\
\text { rupture }\end{array}$ \\
\hline Olsen $(1997)^{8}$ & 26 & $1+1$ & Not known & 7 & Vaginal spotting & 22,140 & Right adnexal mass & $\begin{array}{l}\text { Laparoscopy; right } \\
\text { intraligamentary } \\
\text { pregnancy }<1 \mathrm{~cm} \\
\text { peritoneal separation; } \\
\text { managed with bipolar } \\
\text { scissors and } \\
\text { electrocautery }\end{array}$ \\
\hline $\begin{array}{l}\text { Atalla et al } \\
(1997)^{5}\end{array}$ & 30 & 2 & Not known & 5 & $\begin{array}{l}\text { Abdominal pain, } \\
\text { vaginal bleeding }\end{array}$ & NA & $\begin{array}{l}\text { Intrauterine sac } 6 \mathrm{wk} \text {, } \\
\text { 4-cm right adnexal } \\
\text { swelling fibroid? }\end{array}$ & $\begin{array}{l}\text { Laparoscopy; } 2-\mathrm{cm} \\
\text { cornual fibroid; } \\
\text { miscarriage of } \\
\text { intrauterine pregnancy; } \\
\text { second operation, } \\
\text { hysterectomy: 4-cm right } \\
\text { broad ligament } \\
\text { pregnancy }\end{array}$ \\
\hline $\begin{array}{l}\text { Deshpande et al } \\
(1999)^{12}\end{array}$ & 33 & $0+1$ & $\begin{array}{l}\text { Infertility, endometriosis, } \\
\text { ipsilateral salpingo- } \\
\text { oophrectomy, IVF } \\
\text { pregnancy }\end{array}$ & 9 & Asymptomatic & 55,560 & $\begin{array}{l}\text { 6-cm mass left side of } \\
\text { uterus, CRL } 23 / 20 \mathrm{~mm} \text {, } \\
\mathrm{FH}++\end{array}$ & $\begin{array}{l}\text { Laparotomy; left broad } \\
\text { ligament adherent }\end{array}$ \\
\hline $\begin{array}{l}\text { Phupong et al } \\
(2001)^{7}\end{array}$ & 34 & $0+1$ & Spontaneous twins & 11 & Abdominal pain & NA & $\begin{array}{l}8 \times 10 \mathrm{~cm} \text { left adnexal } \\
\text { mass with } 2 \text { viable } \\
\text { fetuses, CRL } 4.8 / 4.9 \\
\text { mm }\end{array}$ & $\begin{array}{l}\text { Laparotomy; 8-cm ectopic } \\
\text { 200-mL hemoperitoneum }\end{array}$ \\
\hline $\begin{array}{l}\text { Phupong et al } \\
(2003)^{2}\end{array}$ & 38 & $2(\mathrm{C} / \mathrm{S})$ & Not known & 11 & Vaginal bleeding & NA & $\begin{array}{l}\text { Empty uterus, } 6.6-\mathrm{cm} \\
\text { mass, viable fetus at } \\
\text { right side of lower } \\
\text { uterus }\end{array}$ & $\begin{array}{l}\text { Laparotomy; } 2-\mathrm{cm} \\
\text { rupture site; excision and } \\
\text { salpingectomy }\end{array}$ \\
\hline $\begin{array}{l}\text { Siow et al } \\
(2004)^{11}\end{array}$ & 25 & Unknown & Not known & 10 & Asymptomatic & 55.8 & $\begin{array}{l}\text { 5.5-cm right adnexal } \\
\text { mass with CRL } 8 \mathrm{wk}\end{array}$ & $\begin{array}{l}\text { Laparoscopy; } 6.5-\mathrm{cm} \text { right } \\
\text { broad ligament ectopic } \\
\text { pregnancy, vasopressin } \\
\text { injection and excision }\end{array}$ \\
\hline
\end{tabular}




\begin{tabular}{|c|c|c|c|c|c|c|c|c|}
\hline \multicolumn{9}{|c|}{$\begin{array}{l}\text { Table } 1 . \\
\text { Continued }\end{array}$} \\
\hline Study & $\begin{array}{l}\text { Age, } \\
\text { y }\end{array}$ & Parity & Risk Factors & $\begin{array}{l}\text { Gestational } \\
\text { Age (wk) }\end{array}$ & Presentation & $\begin{array}{l}\text { hCG } \\
(\mathrm{IU} / \mathrm{L})\end{array}$ & $\begin{array}{l}\text { Imaging Findings (USG } \\
\text { if Not Specified) }\end{array}$ & Outcome \\
\hline $\begin{array}{l}\text { Apantaku et al } \\
(2006)^{9}\end{array}$ & 33 & $1+2$ & $\begin{array}{l}\text { Previous laparotomy and } \\
\text { bilateral salpingectomy, } \\
\text { IVF pregnancy }\end{array}$ & 8 & Not mentioned & NA & $\begin{array}{l}\text { Empty uterus, right } \\
\text { adnexal mass with CRL } \\
6 \mathrm{wk}\end{array}$ & $\begin{array}{l}\text { Laparoscopy; } 2-\mathrm{cm} \text { broad } \\
\text { ligament pregnancy } \\
\text { below remnant of right } \\
\text { tube }\end{array}$ \\
\hline $\begin{array}{l}\text { Abdul et al } \\
(2008)^{14}\end{array}$ & 29 & 6 & Not known & 22 & Left iliac mass & NA & IUD outside uterus & $\begin{array}{l}\text { Laparotomy; excision and } \\
\text { unilateral salpingo- } \\
\text { oophrectomy }\end{array}$ \\
\hline This study & 30 & $0+1$ & Ipsilateral salpingectomy & 6 & Vaginal bleeding & 15,665 & $\begin{array}{l}\text { Suspected stump } \\
\text { pregnancy, CRL } 5 \mathrm{wk} \\
5 \mathrm{~d} \text { with slow fetal } \\
\text { pulsation }\end{array}$ & $\begin{array}{l}\text { Laparoscopy; } 3 \text {-cm } \\
\text { unruptured right broad } \\
\text { ligament pregnancy; } \\
\text { excision and laparoscopic } \\
\text { suture to obliterate the } \\
\text { space and hemostasis }\end{array}$ \\
\hline
\end{tabular}

CRL, crown-rump length; C/S, cesarean section; FH, fetal heart; hCG, human chorionic gonadotropin; IUD, intrauterine device; IVF, in vitro fertilization; NA, not available; USG, ultrasonography.

by the presence of other symptoms or findings. For instance, misdiagnosis with obstetric and placental abnormalities occurred in a case reported by Mittal et al. ${ }^{4}$ Even with the use of sonography, the ectopic gestation could have been mistaken as another pelvic pathology, such as a uterine fibroid. ${ }^{5}$ Sometimes the diagnosis was made only after failed medical induction or primary surgery, and the ectopic gestation was revealed only on repeat laparotomy. $3,6,15$

It has been commented that there are no clinical features specifically characteristic of this rare form of ectopic pregnancy to enable diagnosis to be made preoperatively. ${ }^{4}$ It thus remains a major diagnostic challenge for clinicians. Indeed, in all but 1 of the cases we identified, the diagnosis was reached only intraoperatively. Phupong et $\mathrm{al}^{7}$ reported a preoperative diagnosis of broad ligament ectopic pregnancy because of previous experience. Neither the history itself nor the preoperative ultrasound provided a specific diagnostic clue in their case. In our patient, diagnosis of suspected ectopic pregnancy stump of previous salpingectomy was suggested by the ultrasound scan. We therefore advise a high index of suspicion in patients with previous tubal surgical procedures, particularly salpingectomy. Ectopic pregnancies at the stumps of the Fallopian tubes as well as those implanted between the broad ligaments should remain in mind as possible differential diagnoses.

Mortality due to massive hemorrhage from ruptured abdominal pregnancy has been well recognized because of the difficulty in making an early diagnosis. Similarly, pregnancy between the broad ligaments can lead to significant maternal morbidity and even mortality. The most common complication was rupture resulting in hemoperitoneum, which was evident in $\geq 5$ of the cases in our review. ${ }^{2,4,5-7}$ Other maternal morbidities included anemia, infection, abscess, toxemia, and coagulopathy. ${ }^{15}$ Most ectopic pregnancies could not reach fetal viability. When they did, the increased risk for fetal morbidities and mortalities such as fetal deformity, abnormal lies, high presenting parts, abnormal labor, and fetal demise would follow. ${ }^{4,15}$

Access to expertise and improvements in sonographic accuracy may help in achieving a preoperative diagnosis and reducing morbidity. Unfortunately, no specific sono- 
graphic criteria have been established so far to aid in reaching this diagnosis. Clinical history, the absence of an intrauterine sac with the finding of an extrauterine pregnancy, and a high index of suspicion are the most important clues to early diagnosis, regardless of gestational age.

With recent advances in laparoscopic surgery, most unruptured nontubal ectopic pregnancies can be managed safely laparoscopically. Surprising, in the recent cases of broad ligament pregnancy reviewed, including our own case, only 6 were managed laparoscopically.,5-11 Successful outcomes were achieved in 5 , all presenting in the first trimester. Olsen ${ }^{8}$ was the first to report laparoscopic treatment of this type of ectopic pregnancy. In a report by Atalla et $\mathrm{al},{ }^{5}$ laparoscopy failed to demonstrate the site of ectopic pregnancy. The combination of a miscarried intrauterine pregnancy with a broad ligament ectopic pregnancy further complicated the picture. The patient eventually underwent hysterectomy for irregular vaginal bleeding and disabling abdominal pain. Siow et al ${ }^{11}$ reported the first successful laparoscopic management of a large broad ligament pregnancy in a hemodynamically stable patient. The use of vasopressin and electrocautery has been reported to achieve hemostasis. ${ }^{8,11}$ In our case, we have also demonstrated the safe use of laparoscopic suturing to achieve hemostasis.

Knowledge of the role of medical therapy in the management of broad ligament ectopic pregnancy is limited. Methotrexate has been used to destroy residual placenta. Others have reported leaving the placenta in situ. However, accumulation of organizing and necrotic tissues could become potential source of infection and risk for peritonitis or abscess formation. ${ }^{13}$ No report on the use of medical treatment of early asymptomatic broad ligament ectopic pregnancy has been published.

In summary, the key to the management of broad ligament ectopic pregnancy involves a high index of suspicion, early diagnosis, and prompt surgery. The occurrence of unusual ectopic pregnancy is likely to increase with the increasing use of assisted reproduction technologies. Clinicians should be aware of the possibility of broad ligament pregnancy in patients with known risk factors. With advances in sonographic diagnosis, laparoscopic instruments, and skills, a broad ligament pregnancy can be safely managed laparoscopically.

\section{References:}

1. Cordero DR, Adra A, Yasin S, O'Sullivan MJ. Intraligamentary pregnancy. Obstet Gynecol Surv. 1994;49(3):206-209.

2. Phupong V, Lertkhachonsuk R, Triratanachat S, Sueblinvong T. Pregnancy in the broad ligament. Arch Gynecol Obstet. 2003; 268(3):233-235.

3. Chia KV, Fayle RJS, Ferriman E. Intraligamentary pregnancy. J Obstet Gynaecol. 1993;13:254.

4. Mittal S, Chhabra P, Khanna R. Advanced abdominal intraligamentary pregnancy with live birth. Int J Gynaecol Obstet. 1994;46(3):327-328.

5. Atalla RK, Murphy PC, Balachandar C. Combined intrauterine and broad ligament ectopic pregnancy. J Obstet Gynaecol. 1997;17(2):203.

6. Olsen ME. Bilateral twin ectopic gestation with intraligamentous and interstitial components. A case report. I Reprod Med. 1994;39(2):118-20.

7. Phupong V, Tekasakul P, Kankaew K. Broad ligament twin pregnancy. A case report. J Reprod Med. 2001;46(2):144-146.

8. Olsen ME. Laparoscopic treatment of intraligamentous pregnancy. Obstet Gynecol. 1997;89(5 Pt 2):862.

9. Apantaku O, Rana P, Inglis T. Broad ligament ectopic pregnancy following in-vitro fertilisation in a patient with previous bilateral salpingectomy. J Obstet Gynaecol. 2006;26(5):474.

10. Cormio G, Ceci O, Loverro G, Bettocchi S. Spontaneous left broad ligament pregnancy after ipsilateral salpingo-oophorectomy. J Minim Invasive Gynecol. 2006;13(2):84-85.

11. Siow A, Chern B, Soong Y. Successful laparoscopic treatment of an abdominal pregnancy in the broad ligament. Singapore Med J. 2004;45(2):88-89.

12. Deshpande N, Mathers A, Acharya U. Broad ligament twin pregnancy following in-vitro fertilisation. Hum Reprod. 1999; 14(3):852-854.

13. Seckin B, Turkcapar FA, Tarhan I, Yalcin HR. Advanced intraligamentary pregnancy resulting in a live birth. $J$ Obstet Gynaecol. 2011;31(3):260-261.

14. Abdul MA, Tabari AM, Kabiru D, Hamidu N. Broad ligament pregnancy: a report of two cases. Ann Afr Med. 2008;7(2):86-87.

15. Schramm M. Advanced intraligamentary pregnancy: a report of 2 cases. Aust N Z J Obstet Gynaecol. 1982;22(4):240-242. 